\title{
EVALUATION OF MANGROVE AND ITS ROLE IN THE ECONOMY AND STRATEGY TO CLIMATE CHANGE: CASE STUDY OF CUIARANA, PARÁ, IN THE BRAZILIAN AMAZON
}

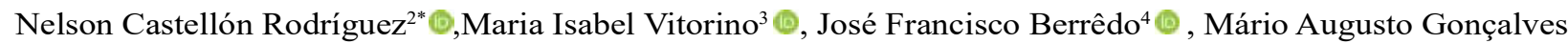 \\ $\operatorname{Jardim}^{4} \odot$,Adriano Marlison Leão de Sousa ${ }^{5} \cdot$ and Paulo Vinicius Caldas da Silva ${ }^{6}$

\footnotetext{
${ }^{1}$ Received on 11.03.2019 accepted for publication on 30.08.2019.

${ }^{2}$ Universidade Federal do Pará, Programa de Pós-Graduação em Ciências Ambientais, Belém, PA-Brasil. E-mail: <castellon@gmail.com>.

${ }^{3}$ Universidade Federal do Pará, Faculdade de Meteorologia, Belém, PA-Brasil. E-mail: <vitorino@ufpa.br>.

${ }^{4}$ Museu Paraense Emílio, Belém, PA-Brasil. E-mail: < berredo@museu-goeldi.br $>$ and <jardim@museu-goeldi.br $>$.

${ }^{5}$ Universidade Federal Rural da Amazônia, Departamento de Hidromecânica e Hidrologia, Belém, PA-Brasil. E-mail: <adriano.sousa@ gmail.com>.

${ }^{6}$ Universidade Federal Rural da Amazônia,Graduado em Engenharia Ambiental, Belém, PA-Brasil. E-mail: <pvinicius@gmail.com>.
} \\ *Corresponding author.
}

\begin{abstract}
This research aimed to estimate the seasonal economic value of ecosystem goods and services from research on the use of mangroves in the Cuiarana community in the Eastern Amazon. The methodology of Total Economic Value was used, through interviews with 15 residents who extract products from the mangrove. For the ecosystem services, atmospheric carbon (measured by a micrometeorological tower), and organic carbon (monitored by soil sampling during 2017) were used. In determining product values, the quantities extracted at market prices and the value of services were estimated using carbon credits. The results indicate that the ecosystem produces 9 community assets, that generate R $\$ 75,033.50$ (US\$ 23,622.93 ha/year) and R\$ 17,627.15 (US\$ 5,549.58 ha/year) for capture and storage respectively. The VET value corresponded to R\$ $986,132.50$ (US\$ 310,465.79). Ecosystem services and the economic values of atmospheric $(p=0.0278)$ and soil carbon credit $(\mathrm{p}=0.0354)$ indicated higher importance in the rainy season due to the precipitation that favored an increase in the amount of carbon. This behavior was verified by the Principal Components Analysis $(50.1 \%)$, which showed that in the less rainy season goods are more important when compared to the ecosystem services.
\end{abstract}

Keywords: Services; Economic Values; Carbon.

\section{AVALIAÇÃO DO MANGUEZAL NA ECONOMIA E ESTRATÉGIA DE MUDANÇA DO CLIMA: ESTUDO DE CASO DE CUIARANA, PARÁ, NA AMAZÔNIA BRASILEIRA}

\begin{abstract}
RESUMO - Esta pesquisa teve como objetivo estimar o valor econômico sazonal dos bens e serviços ecossistêmicos a partir da pesquisa sobre o uso de manguezais na Comunidade de Cuiarana, na Amazônia Oriental. Foi utilizada a metodologia do Valor Econômico Total, através da entrevista com 15 moradores que extraem produtos do manguezal. Para os serviços ecossistêmicos, utilizou-se o carbono atmosférico medido por uma torre micrometereológica e carbono orgânico monitorado por amostragem de solo em 2017. Na determinação dos valores dos produtos, as quantidades extraídas pelos preços de mercado e o valor dos serviços foram estimados utilizando créditos de carbono. Os resultados indicam que o ecossistema produz 9 bens para a comunidade em torno de R\$ 75.033,50 (US \$23.622,93 ha/ ano) e R\$17.627,15 (US \$ 5.549,58 ha / ano) para a captura e armazenamento. O valor-VET correspondeu a R\$ 986.132,50 (US \$ 310.465, 79). Os serviços ecossistêmicos e os valores econômicos do crédito de carbono atmosférico $(p=0,0278)$ e do solo $(p=0,0354)$ indicaram maior importância na estação chuvosa devido a precipitação que favoreceu a maior quantidade de carbono. Esse comportamento foi constatado pela Análise de Componentes Principais (50,1\%), que mostrou que na estação menos chuvosa os bens são mais importantes quando comparados aos serviços ecossistêmicos.
\end{abstract}

Palavras-Chave: Serviços; Valores Econômicos; Carbono.

Silf $(\boldsymbol{C o}) \mathrm{EY}$

Revista Árvore 2019;43(5):e430503 http://dx.doi.org/10.1590/1806-90882019000500003 


\section{INTRODUCTION}

Mangrove is a productive and biologically important ecosystem of the world, as it directly and indirectly supplies essential goods and services to populations such as fish, shellfish, wood, sediment and nutrient retention, protection against natural phenomena and carbon storage (Barbier et al., 2011; Engle, 2011; Giri et al., 2010). It occupies an abundant and diversified narrow strip in the tropical region and integrates several ecosystem services valued at approximately US \$200,000/ha annually (Costanza et al., 2014).

For Braat and Groot (2012), mangroves also provide raw materials such as wood, and a host of other ecosystem services including regulating services (coastal protection, carbon sequestration, erosion control and water purification), cultural services (tourism, recreation, education and research. The benefits of mangroves become an economic source of subsistence, providing the well-being of society (Vo et al., 2012), as evidenced by Singh et al. (2010), in India when they estimated that the extraction of nontimber products from mangrove forests contributed $79 \%$ to household incomes.

The mangrove plays a fundamental role in the control of atmospheric carbon emissions since it stores more quantity in the deeper layers of the soil (Donato et al., 2011). This ecosystem is recognized as a potential carbon sink and the key to carbon sequestration of biomass and soil (Adame et al., 2013; Alongi, 2014). Carbon sequestration reinforces mangrove maintenance and conservation as strategies for sustainable income generation and high productivity (Alongi, 2002; McLeod et al., 2011).

Mangroves decline at an annual rate of $0.7-3 \%$ caused by natural, human and deforestation impacts (Alongi, 2002; Fao, 2007; Lo et al., 2011). The high carbon sequestration potential can be a sustainable commercial alternative (Alongi, 2011; Donato et al., 2010; Fourqurean et al., 2012; Murdiyarso et al., 2015). In this context, Russell and Greening (2015), estimated values of up to US \$23,000.0 for carbon sequestration in the mangroves of Tampa Bay, Florida.

The objective of this research was to estimate the seasonal economic value of the more important and traditional local ecosystem goods and services from the research on the use of mangroves and the use of mangrove in the village of Cuiarana in the Eastern Amazon. The hypothesis tested is that the mangrove are key ecosystems locally and globally because of their socio-economic and environmental importance, providing high-value goods to local communities and ecosystem services such as carbon dioxide capture and storage, becoming a mitigation strategy for climate change and of economic contribution through carbon credits represent additional income associated with the Total Economic Value of the ecosystem.

\section{MATERIAL AND METHODS}

The study area comprises the mangrove of the Experimental Site of the Federal Rural University of Amazonia (UFRA) and the Federal University of Pará (UFPA), located in the village of Cuiarana, in the municipality of Salinópolis-PA $\left(0^{\circ} 40^{\prime} \mathrm{S}\right.$ and $47^{\circ} 17$ 'WE). It is an area that belongs to the northeastern mesoregion of Paraense and the Salgado micro-region. The rainy season occurs in the months of December to May and the least rainy from June to November. According to Moraes et al. (2005) precipitations vary between 1,800 and $2,300 \mathrm{~mm}$, and about $90 \%$ are distributed in the first six months of the year.

The Total Economic Analysis was based on the Modified methodological proposal of Total Economic Value (VET) of Carandang et al. (2013); Groot et al. (2002) and Goicochea (2011), estimating mainly the values of different uses, classifying use goods (marine and forest products) and non-use goods $\left(\mathrm{CO}_{2}\right.$ capture and storage): VET = (VUD + VUI) Where; VET: Total Economic Value; VUD: Direct use value, VUI: Indirect use value.

The direct use assets were obtained through the case study methodology that involved 15 community respondents from an inventory of residents (100) that has a direct link as the mangrove for their subsistence, and then defined a sample of $15 \%$ according to Fidelman (2001) through a focal group composed of 15 direct users of the mangrove, due to the limited availability of time for community members for interviews. To define the types of uses were added the goods used per month of each interviewee and for the calculation of the economic value of the extractive activities were added the quantities of goods by each

Revista Árvore 2019;43(5):e430503 
respondent and multiplied by the average prices in the market. Given that many mangrove goods do not have a market price (for example firewood) because their marketing is prohibited, the community defined symbolic prices in order to make a better estimate of the goods for direct use of the ecosystem. Non-use goods were obtained from a series of $\mathrm{CO}_{2}$ flux data measured by the $10 \mathrm{~m}$ Micrometeorological Tower installed in the vicinity of the mangrove under study with the aid of the EC-150 instrument, measured every 10 minutes during the year 2017 and calculated the seasonal and annual carbon credits.

The analysis of the carbon credits was calculated by the seasonal and annual $\mathrm{CO}_{2}$ (carbon dioxide) flow from the processing of the high frequency data to obtain the seasonal mean flows by means of a balance of $\mathrm{CO}_{2}$ flows (daytime flows less nocturnal flows), from the flows of $\mathrm{CO}_{2}$ was calculated as the CDM certified currency, as proposed by Fonseca (2010). The calculation comprises the conversions of units of the $\mathrm{CO}_{2}$ flows for the unit considered as CERs emission and then the certified currency. For the calculation of the CDM certified currency (CERs), the average value of the carbon balance in micromol square meters per second $\left(\mu \mathrm{mol} . \mathrm{m}^{-2} . \mathrm{s}^{-1}\right)$ was converted. Thus, $\mu \mathrm{mol}$ for gram, taking into account the molar mass of the $\mathrm{CO}_{2}$, then the conversion to grams. $\mathrm{m}^{-2} \cdot \mathrm{s}^{-1}$ (grams per square meter per second), the conversion was done from seconds to one year and from $\mathrm{m}^{2}$ to hectare to reach the value in $\mathrm{TCO}_{2} \mathrm{e} / \mathrm{ha} / \mathrm{year}$ (tons of carbon equivalent hectare per year). This generated a carbon dioxide balance per hectare (ha) and then calculated the carbon credits under the LULUCF modality (Land use and Change Forest) of the Kyoto Protocol for 20 years (Global Warming Potential Time horizon according to IPCC 2001) and 15.000,0 ha (projects classified as small-scale CDM project activities). The result of the $\mathrm{CO}_{2}$ balance was multiplied by 15,000 ha and for 20 years. The result was multiplied by the price of carbon credits (in Real or Dollar) and divided between 15,000 ha and soon divided between 20 years to know the income per ha.

The organic carbon contents were analyzed in a total number of nine plots, were randomly established to collect $1 \mathrm{~kg}$ soil during each season of the two seasons, Less Rainy Season (November 2017) and Rainy Season Less Rainy Season (May 2017). Total Organic Carbon (TOC) levels measured in nine $20 \mathrm{x}$
$20 \mathrm{~m}$ plots up to $20 \mathrm{~cm}$ depth were used to quantify the soil organic carbon stored in the soil and applied to the Kauffman and Donato (2012): C.O $\left(\right.$ tn $\left.\left.\mathrm{ha}^{-1}\right)\right)=\mathrm{DR}(\mathrm{g}$. $\left.\mathrm{cm}^{-3}\right) *$ I.A $(\mathrm{cm}) * \% \mathrm{C}$

where: $\mathrm{C} . \mathrm{O}=$ Carbon in soil; $\mathrm{DR}=$ Relative Density; I.A = Sampling Interval; \% C = Percentage of Carbon.

To calculate the tons of carbon equivalent, the average levels of organic carbon per hectare per year (tC/ha/year) were used in the rainy and less rainy period and multiplied by the conversion factor 3.67 (ratio of molecular weight of $\mathrm{CO}_{2}$ is 44 and carbon $12=3.67)$ according to the Howard et al. (2014). The value of this ratio was multiplied by the price of the carbon credit to calculate the rent for stored carbon.

The price of carbon credit will depend on the market defined. In this study, the price of US \$ 20.00 (R\$ 63,526.0) per carbon credit was adjusted based on a World Bank Goup price range (2017) with the exchange rate on $08 / 08 / 2017$ of $\mathrm{R} \$ 3.1763$ per US Dollar on the website of the Central Bank of Brazil.

Total Economic Value (VET) was calculated from the sum of the economic values of the assets (direct use) and the values estimated by carbon credits for the capture and storage of carbon in the soil (indirect use) and multiplied by 12.5 ha corresponding to the size of the studied mangrove. The economic values are presented in Brazilian Reais and American Dollars.

\section{RESULTS}

\subsection{Direct benefits: mangrove goods}

In the temporal analysis of quantities and types of mangrove goods (Fig. 1), the extracted products are represented by nine categories of forest and marine products: wood, firewood, fish, crab (Ucides cordatus), (Calinectes sp.), mussels (Limnoperma fortunei), Turú (Teredo sp.), Shrimp (Litopenaeus schmitti) and Sarnambi (Lucina pectinata) which are obtained throughout the year. Among the nine products, the crab is characterized by abundance and commercial demand. The largest amount extracted from the products, mainly from the crab, occur in the less rainy period, in June and July. The crab is the product that is extracted more frequently and in greater quantity by the families mainly for the sale.

\section{Revista Árvore 2019;43(5):e430503}

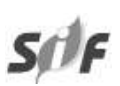




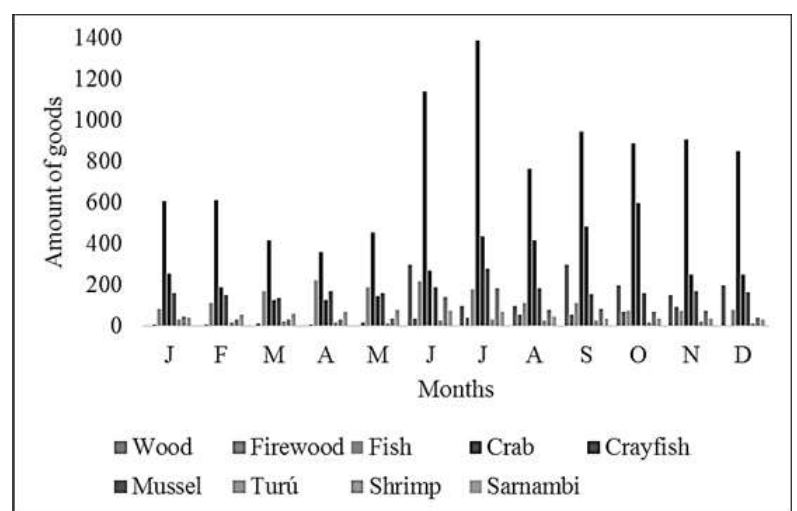

Figure 1- Time variation of the amount of mangrove property extraction in Cuiarana Village, Salinópolis, Pará, Brazil.

Figura 1 - Variação temporal da quantidade de extração dos bens do manguezal na Vila de Cuiarana, Salinópolis, Pará, Brasil.

With $76.2 \%$ of the total variance (PC1/PC2), the variables Crab, Siri, Firewood, Shrimp, Mussel and Turkey present negative correlations and months associated with these variables: July, August, September, October, and November. Atmospheric and organic carbon, Sarnambi and Pisces present positive correlations and the months associated with these variables are; January, February, March, April, May (Fig.2). This result may be favored by the environmental conditions that are conducive to carbon capture and storage.

He table 1 presents the estimated economic value per hectare per year for the direct withdrawal of mangrove goods, equivalent to approximately R\$

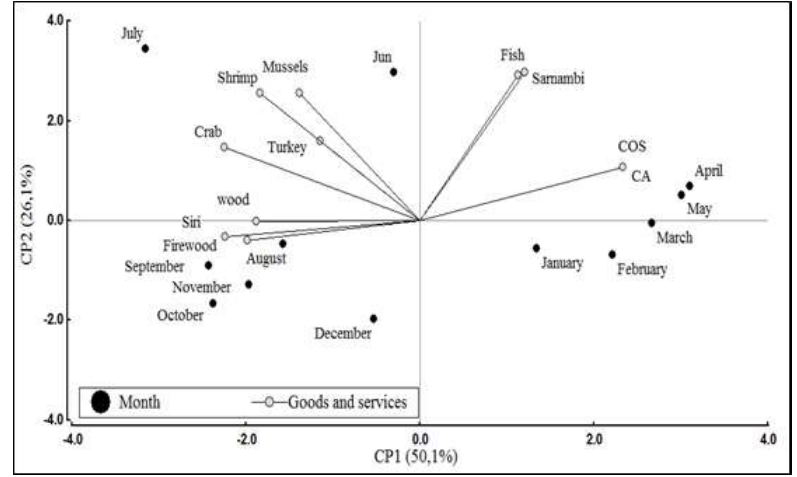

Figure 2 - Principal Component (PC) of the monthly importance of mangrove goods and services in the village of Cuiarana, Salinópolis, Pará, Brazil.

Figura 2 - Componente Principal (PC) da importância mensal dos bens e serviços de mangue no município de Cuiarana, Salinópolis, Pará, Brasil.

$75,033.50$ (US $\$ 23,622.93$ ), but with the contribution of $35 \%$ of the mussel, $13 \%$ of the shrimp, $12 \%$ of the crab, $12 \%$ of sarnambi and the rest of the goods with $28 \%$.

Seasonality influences mangrove property in order to present the highest economic yields of $61 \%$ of the annual total in the least rainy season, with the highest incomes with mussels (31\%), shrimp $(16 \%)$ and crabs $(13 \%)$. In the rainy season, the most valuable products are mussels $(41 \%)$, sarnambi $(17 \%)$, fish $(12 \%)$ and crayfish $(11 \%)$. Thus, the results confirm that it is precisely in the less rainy period, more specifically in July, that the majority of respondents $(55 \%)$ more frequent the mangroves for the extraction of their products. This result may be

Table 1 - Sazonal Economic value of the goods in the mangrove in the in the rainy season and Less rainy season in the village of Cuiarana, Salinópolis, Pará, Brazil.

Tabela 1 - Valor econômico da atividade extrativista no manguezal na Vila de Cuiarana, Salinópolis, Pará, Brasil.

\begin{tabular}{|c|c|c|c|c|c|c|c|c|}
\hline Goods & $\begin{array}{c}\mathrm{U} \\
\text { Measure }\end{array}$ & $\begin{array}{l}\text { G. } \\
\text { T. }\end{array}$ & $\begin{array}{l}\text { G. } \\
\text { RS }\end{array}$ & $\begin{array}{c}\text { G. } \\
\text { LRS }\end{array}$ & $\begin{array}{c}\text { A. } \\
\text { V }(\mathrm{R} \$)\end{array}$ & $\begin{array}{c}\text { I.T } \\
(\mathrm{R} \$)\end{array}$ & $\begin{array}{l}\text { I.RS } \\
(\mathrm{R} \$)\end{array}$ & $\begin{array}{c}\text { I.LRS } \\
(\mathrm{R} \$)\end{array}$ \\
\hline Wood & $M$ & 675 & 100 & 575 & 10 & 6,750 & 1,000 & 5,750 \\
\hline Firewood & $\mathrm{U}$ & 212 & 33 & 179 & 1 & 212 & 33,5 & 178 \\
\hline Fish & $\mathrm{Kg}$ & 824 & 432 & 392 & 8 & 6,592 & 3,460 & 3,132 \\
\hline Crab & $\mathrm{U}$ & 4,678 & 1,655 & 3,023 & 2 & 9,356 & 3,311 & 6,045 \\
\hline Crayfish & $\mathrm{U}$ & 1,784 & 552 & 1,232 & 3 & 5,352 & 1,656 & 3,696 \\
\hline Mussels & Can & 1,046 & 483.0 & 564 & 25 & 26,162 & 12,087 & 14,075 \\
\hline Turú & Can & 143 & 62.0 & 82.0 & 15 & $2,152.5$ & 930 & $1,222.5$ \\
\hline Shuimp & $\mathrm{Kg}$ & 437 & 114.0 & 323 & 22 & $9,614.0$ & 2,508 & 7,106 \\
\hline Sarnambi & Can & 327 & 172.0 & 156 & 27 & $8,842.5$ & 4,630 & 4,212 \\
\hline I/ha (R\$) & & & & & & 75,033 & 29,616 & 45,417 \\
\hline I./ha (US \$) & & & & & & 23,623 & 9,324 & 14,298 \\
\hline
\end{tabular}

$\mathrm{M}=$ Meters, U=Units, Kg= kilograms, I/ha=Income hectare, G.T=Goods Total, G.RS = Goods Rainy Season, G.LSR= Less Rainy Season, A.V= Average Value, I.T= Income Total, I.RS= Income Rainy Season, I.LRS= Income Less Rainy Season, R\$= Brazilian Real, US \$= American Dollars. 
Table 2 - Sazonal economical value associated with carbon credits (mean value of carbon credits = US \$20.0) based in atmospheric carbon in the mangrove forest in the in the rainy season and Less rainy season in Cuiarana, Salinópolis, Pará, Brazil.

Tabela 2 - Valor econômico sazonal associado a créditos de carbono (valor médio de créditos de carbono $=$ US \$20,0) baseado em carbono atmosférico no manguezal no periodo chu'voso e menos chuvoso em Cuiarana, Salinópolis, Pará, Brasil.

\begin{tabular}{|c|c|c|c|}
\hline $\begin{array}{l}\text { Variables } \\
\text { Season }\end{array}$ & $\begin{array}{l}\text { Rainy } \\
\text { Season }\end{array}$ & $\begin{array}{c}\text { Less Rainy } \\
\text { Income }\end{array}$ & Total \\
\hline TCO2e/ha/year a & 32.32 & 28.40 & 60.72 \\
\hline $\begin{array}{l}\text { TCO2e/ha/year } \\
\text { (15000ha) }\end{array}$ & $9696,000.0$ & $8520,000.0$ & $18216,000.0$ \\
\hline $\begin{array}{l}\mathrm{R} \$ / 15000 \mathrm{ha} \\
\text { (20 years) }\end{array}$ & $615948,096.0$ & $541241,520.0$ & $1157189,616.0$ \\
\hline $\begin{array}{l}\text { US \$/15000ha } \\
\text { ( } 20 \text { years) }\end{array}$ & $193920,000.0$ & $170400,000.0$ & $364320,000.0$ \\
\hline R\$ ha/year & $2,053.16$ & $1,804.14$ & $3,857.30$ \\
\hline US \$ ha/year & 646.4 & 568.0 & $1,214.4$ \\
\hline
\end{tabular}

related to the greater accessibility by the decrease of the precipitations in the zone.

The table 2 shows the economic analysis of carbon credits based on LULUCF-CDM projects in 15,000 ha, this calculation suggests a 20 -year scenario and having as reference the $60.72 \mathrm{TCO}_{2} \mathrm{e} / \mathrm{ha} / \mathrm{year}$ ( 60.72 certificates / credits) withdrawn by mangrove per hectare assuming prices of R $\$ 63,526$ (US \$ 20) per ton of carbon. The estimated economic value corresponded to $\mathrm{R} \$ 3,857.30$ (US $\$ 1,214.40$ ) per hectare per year.

The economic analysis of the carbon credits by carbon storage using the reference to the 216,76 $\mathrm{TCO}_{2} \mathrm{e} / \mathrm{ha} /$ year stored per hectare $(20 \mathrm{~cm}$ depth$)$

Table 3 - Total Economic Value in the mangrove associated with atmospheric carbon and soil carbon in the village of Cuiarana, Salinopólis, Pará, Brazil.

Tabela 3 - Valor Econômico Total no manguezal associado com o carbono atmosférico e arbono do solo na vila de Cuiarana, Salinopólis, Pará, Brasil.

\begin{tabular}{lcccc}
\hline $\begin{array}{l}\text { Goods and } \\
\text { Services }\end{array}$ & $\begin{array}{c}\text { Economic } \\
\text { Value } \\
\text { R/ha/year }\end{array}$ & $\begin{array}{c}\text { Studied } \\
\text { Area } \\
\text { hectare }\end{array}$ & $\begin{array}{c}\text { Total } \\
\text { Economic } \\
\text { Value } \\
(\mathrm{R} \$)\end{array}$ & $\begin{array}{c}\text { Total } \\
\text { Economic } \\
\text { Value } \\
\text { (US \$) }\end{array}$ \\
\hline Mangrove & $75,033.50$ & 12.5 & $937,918.75$ & $\begin{array}{c}295,314.47 \\
\text { good }\end{array}$ \\
$\begin{array}{l}\text { Atmospheric } \\
\text { carbon }\end{array}$ & $3,857.10$ & 12.5 & $48,213.75$ & $15,180.65$ \\
Soil Carbon & $13,770.05$ & 12.5 & $96,559.52$ & $30,402.87$ \\
\hline Total & $92,660.65$ & - & $986,132.50$ & $340,897.99$ \\
\hline R\$ = Brazilian Reais, US \$ = US Dollars, ha=hectare &
\end{tabular}

assuming prices of $\mathrm{R} \$ 63,526$ (US $\$ 20$ ) per ton of carbon equivalent. The estimated economic value corresponded to R $\$ 13,770.05$ (US $\$ 4,335.25$ ) per hectare per year, of which $63 \%$ corresponded to the rainy season.

The table 3 shows the estimated Economic Value for 12.5 hectares referring to the study area. The highest economic value in the ecosystem corresponds to goods with R $\$ 75,033.50$ (US \$ 23,622.93), the service, capture of atmospheric carbon R\$ 3,857.10 represents (US \$1,214.34) and the storage of $\mathrm{CO}_{2}$ in the soil R\$13,770.05 (US \$ 4,335.25) per hectare per year. The Economic Value in the total area studied (12.5 ha) corresponded to $\mathrm{R} \$ 986,132.50$ (US \$ 310,465.79).

The ANOVA test revealed that, there was a significant difference between the economic value to goods, atmospheric carbon credit and soil carbon credit $(p=0.0237)$ and Tukey's test indicated greater statistical importance of atmospheric carbon credit $(p=0.0278)$ and soil carbon credit $(p=0.0354)$ when compared with goods mainly in the rainy season due to difficulty of extraction of goods due to adverse environmental conditions inside the mangrove.

\section{DISCUSSION}

The extracted products in this mangrove are represented by nine categories of forest and marine products and the largest amount extracted from the products, mainly from the crab. Mojiol et al. (2016), studying the mangrove in Sabah, Malaysia have shown that mangrove products can be divided into nine categories (marine, firewood, building materials, medical values, household uses, fishing, food/ beverages, decoration/and shells). Warren-Rhodes et al. (2011), studying mangrove ecosystem goods in Solomon Islands identified 30 types of mangrove goods nearly $75 \%$ were classified as important or very important.

Goods like crab is the product extracted for commercial purposes with more frequency and quantity by the families. It is the second largest crustacean of Brazilian mangroves, and one of the most commercially exploited resources in the north and northeast regions of Brazil (Pinheiro et al., 2005). It is an economic and subsistence resource in all mangrove areas in Brazil (Alves and Nishida, 2002; 
Glaser and Diele, 2004; Carvalho and Jardim, 2019). In Bragança, northeastern Pará, the crab is collected and sold by $42 \%$ of the population and accounts for $38 \%$ of local income Glaser (2003).

The significance of atmospheric carbon and organic carbon in the rainy season is a result related to environmental conditions, since $90 \%$ of rainfall in this zone is distributed in the first six months of the rainy season (Moraes et al., 2005). This argument is in agreement with McLeod and Salm (2006), argue that with the decrease in precipitation rates mangrove productivity decreases by the effect on its growth and mangrove survival.

The estimated economic value per hectare per year for the direct withdrawal of mangrove goods, equivalent to approximately $\mathrm{R} \$ 75,033.50$ (US \$ $23,622.93$ ) and least rainy season present the highest economic yields of $61 \%$ of the annual total. Barbier (2000) and Rönnbäck (1999), estimated the annual market value of crustaceans, molluscs, shrimp and fish, which depend directly or indirectly on the mangrove during its life cycle and the value of the mangroves associated with its support function (eg primary production, biodiversity, nutrient cycle) ranged from US \$ 750 to US \$ $16,750.0$ per hectare per year. According Moraes et al. (2005), in this area, about $90 \%$ of the precipitation is distributed in the first six months of the year that represents the rainy season this environmental situation could favor the extraction of species.

The total annual atmospheric $\mathrm{CO}_{2}$ of catch of $60.72 \mathrm{TCO}_{2} \mathrm{e} / \mathrm{ha} / \mathrm{year}$ and highest capture occurs in the Rainy Season with $32.32 \mathrm{TCO}_{2} \mathrm{e} / \mathrm{ha} /$ year. This result differs from that found by Fonseca (2005), in the Itaipu mangrove, Rio de Janeiro, which reports $76.09 \mathrm{TCO}_{2} \mathrm{e} / \mathrm{ha} /$ year of atmospheric carbon captured. Kairo et al. (2009), studying a mangrove stretch in Kenya with Rhizophora dominance showed that carbon sequestration was equivalent to $53.3 \mathrm{TCO}_{2} \mathrm{e} /$ ha/year, corroborating the values recorded in this study. The high $\mathrm{CO}_{2}$ capture capacity is evident when comparing other tropical species such as pine (Pinus spp.) and eucalyptus (Eucalyptus spp.) with $38.6 \mathrm{TCO}_{2} \mathrm{e} / \mathrm{ha} / \mathrm{year}$ of carbon captured as indicated by Fonseca (2010). The economic analysis of carbon credits based on LULUCF-CDM projects is estimated economic value corresponded to R $\$ 3,857.30$ (US $\$ 1,214.40)$ per hectare per year and the economic analysis of the carbon credits by carbon organic storage in the mangrove soil is estimated in $\mathrm{R} \$$ $13,770.05$ (US $\$ 4,335.25$ ) per hectare per year, of which $63 \%$ corresponded to the rainy season.

Was estimated that the minimum carbon credit value for the mangrove forest in the Sungai Haji Dorani (SHD) and Kuala Selangor Nature Park (KSNP) was US \$ 3,314.23 ha $\mathrm{ha}^{-1}$ and US \$ 5,89.83 ha $\mathrm{ha}^{-1}$ (Hong et al., 2017), and according to Donato et al. (2011), soils are the most decisive for carbon fate in mangroves when storing up to $98 \%$ of carbon. Kairo et al. (2009), assuming prices of US \$ 10 per tonne of carbon, estimated that the Gazi Bay, Kenya, mangrove generated income of US \$ 533.00 per hectare. The highest economic value in the ecosystem corresponds to goods with $\mathrm{R} \$ 75,033.50$ (US $\$ 23,622.93$ ), the service, capture of atmospheric carbon R\$ 3,857.10 represents (US \$1,214.34) and the storage of CO2 in the soil R $\$ 13,770.05$ (US $\$ 4,335.25$ ) per hectare per year and the total area studied (12.5 ha) corresponded to $\mathrm{R} \$ 986,132.50$ (US \$ 310,465.79).

Salem and Mercer (2012), studying economic goods and services of mangroves in different continents (Africa, Asia and America) concluded that 1 hectare of mangrove yields US $\$ 30,864.00$ a year in seafood (fish, shellfish) and forestry US \$ 4,265.00 for carbon sequestration. Russell and Greening (2015), estimated values of up to US $\$ 23,000$ for carbon sequestration in the Tampa Bay, Florida mangroves. Constanza et al. (1997), reported a VET of ecosystem services in mangroves of US \$ 9,990.00 ha/year. Values of lower goods and services were demonstrated by Brander et al. (2012), when they recorded a value of US \$ 4,185.00 ha/year for a mangrove in Southeast Asia and from US \$ 685.8 to $1,038.70 \mathrm{ha} /$ year for different mangrove uses in Palawan and Bohol, Philippines (Carandang et al., 2013). Sathirathai and Barbier (2001), estimated economic value of mangrove forests to a local community in southern Thailand is in the range of US $\$ 27,264.0$ - US \$ 35,921.0 ha/year.

Constanza et al.(1997), reported a VET of ecosystem services in mangroves of US \$ 9,990.00 ha/year. Values of lower goods and services were demonstrated by Brander et al. (2012), when they recorded a value of US \$ 4,185.00 ha/year for a mangrove in Southeast Asia and from US \$ 685.8 to $1,038.70$ ha/year for different mangrove uses in Palawan and Bohol, Philippines (Carandang et al., 2013). 


\section{CONCLUSION}

Mangroves are an economically strategic ecosystem of great importance to coastal families who have a subsistence economy by providing goods of high demand and high market value throughout the year, but more prominently in the less rainy period of the region in the case of assets. Based on the VET methodology, the economic income according to the total area was estimated in $\mathrm{R} \$ 986,132.50$ (US \$ 310,465.79) or RS 92,660.65 per hectare per year. Estimates of the atmospheric carbon capture capacity and storage in the soil of the mangrove have shown superiority when compared to other ecosystems, allowing it to be an ecosystem of local and global economic value, being able to be useful for the mechanisms of the RECs and to become a complementary economic source.

\section{ACKNOWLEDGMENTS}

The authors thank the residents of the village of Cuiarana, Salinópolis, Pará for the information given at the time of the interviews. To the Large-scale BiosphereAtmosphere Project (LBA) for the facilitation of carbon dioxide data. To the Museu Paraense Emilio Goeldi for assistance in soil carbon analysis.

\section{REFERENCES}

Adame MF, Kauffman JB, Medina I, Gamboa JN, Torres O, Caamal, JP, et al. Carbon stocks of tropical coastal wetlands within the karstic landscape of the Mexican Caribbean. PLOS ONE. 2013;8(2):1-13.

Alongi DM. Present state and future of the world's mangrove forests. Environmental Conservation. 2002;29(3):331-349. doi: https://doi.org/10.1017/ S0376892902000231.

Alongi DM. Carbon payments for mangrove conservation: ecosystem constraints and uncertainties of sequestration potential. Environmental Science \& Policy. 2011;14(4):462-470. http://doi.org/10.1016/j. envsci.2011.02.004

Alongi DM. Carbon cycling and storage in mangrove forests. Annual Review of Marine Science. 2014;6:195-219. doi: https://doi.org/10.1146/annurevmarine-010213-135020.

Alves RRN, Nishida AK. A Ecdise do Caranguejo- uçá, Ucides cordatus L. (Decapoda, Brachyura) na Visão dos Caranguejeiros. Interciência. 2002;27(3):110-117.

Barbier EB. Valuing the environment as input: review of applications to mangrove-fishery linkages. Ecological Economics. 2000;35(1):47-61.

Barbier EB, Hacker SD, Kennedy C, Koch EW, Stier AC, Silliman BR. The value of estuarine and coastal ecosystem services. Ecological Monographs. 2011;81(2):169-193. https://doi.org/10.1890/10-1510.1.

Brander LM, Wagtendonk AJ, Hussain SS, McVittie A, Verburg PH, Groot RS, et al.. Ecosystem service values for mangroves in Southeast Asia: a meta-analysis and value transfer application. Ecosystem Services. 2012;1(1):62-69. doi: http://doi. org/10.1016/j.ecoser.2012.06.003.

Braat LC, Groot R. The ecosystem services agenda: bridging the worlds of natural science and economics, conservation and development, and public and private policy. Ecosystem Services. 2012;1(1):4-15. doi: https://doi.org/10.1016/j.ecoser.2012.07.011.

Carandang AP, Camacho LD, Gevaña DT, Dizon JT, Camacho SC, Luna CC, et al. Economic valuation for sustainable mangrove ecosystems management in Bohol and Palawan, Philippines. Forest Science and Technology. Forest Science and Technology. 2013;9(3):118-125. https://doi.org/10.1080/21580103. 2013.801149 .

Carvalho EA, Jardim MAG. Usos sociais do manguezal por comunidades tradicionais no estado do Pará, Brasil. Biota Amazônia. 2019;9(2):43-46. doi: http://dx.doi.org/10.18561/2179-5746.

Costanza R, D’arge R, Groot R, Farber S, Grasso M, Hannon B, et al. The value of the world's ecosystem services and natural capital. Nature. 1997;387:253-260.

Costanza R, Groot R, Sutton P, van der Ploeg $\mathrm{S}$, Anderson SJ, Kubiszewski I, et al. Changes in the global value of ecosystem services. Global Environmental Change. 2014;26:152-158. doi: http:// doi.org/10.1016/j.gloenvcha.2014.04.002.

Groot RS, Wilson MA, Boumans RMJ. A typology for the classification, description and valuation of ecosystem functions, goods and services. Ecological 
Economics. 2002;41(3):393-408.

Donato DC, Kauffman JB, Mackenzie RA, Ainsworth A, Pfleeger AZ. Whole island carbon stocks in the tropical Pacific: Implications for mangrove conservation and upland restoration. Journal of Environmental Management. 2012;97:89-96. doi: https://doi.org/10.1016/j. jenvman.2011.12.004.

Donato DC, Kauffman JB , Murdiyarso D, Kurnianto S, Stidham M, Kanninen M. Mangroves among the most carbon-rich forests in the tropics. Nature Geoscience. 2011;4:293-297. doi: http://doi. org/10.1038/ngeo1123.

Engle VD. Estimating the provision of ecosystem services by Gulf of Mexico coastal wetlands. Wetlands. 2011;31(1):179-193. doi: http://doi. org/10.1007/s13157-010-0132-9.

Fidelman PIJ. Manguezais do rio Santana, Ilhéus, Bahia: caracterização do sistema (1). Revista de estudos ambientais. 2001;3(1):86-94.

Food and Agriculture Organization of the United Nations - FAO. The world's mangroves 1980-2005. Publishing Physics Web. http://www.fao.org/docrep/ pdf/010/a1427e/a1427e00.pdf. 2007. Accessed 02 de October 2018.

Fonseca SM. O MDL e as florestas de mangue: avaliação preliminar sobre a geração de CERs a partir de atividades de projeto para recuperação de ecossistemas manguezais. Biomassa e Energia. 2005;2:241-250.

Fonseca SM. Avaliações diárias e sazonais das concentrações de co2 em um ecossistema de manguezal: dimensões micrometeorológicas e econômicas. [Tese de Doutorado]. Viçosa (MG): Universidade Federal de Viçosa; 2010.

Fourqurean JW, Duarte CM, Kennedy H, Marbà N, Holmer M, Mateo MA, et al. Seagrass ecosystems as a globally significant carbon stock. Nature Geoscience. 2012;5:505-509. doi: http://doi. org/"10.1038/ngeo1477".

Giri C, Ochieng E, Tieszen LL, Zhu Z, Singh A, Loveland T, et al. Status and distribution of mangrove forests of the world using earth observation satellite data. Global Ecology and Biogeography. 2010;20(1):154-159. doi: https://doi. org/10.1111/j.1466-8238.2010.00584.x.

Goicochea ZIN. Valoración económica del patrimonio natural: las áreas naturales protegidas. Espacio y Desarrollo. 2011;23:131-154.

Glaser M. Interrelations between mangrove ecosystem, local economy and social sustainability in Caeté Estuary, North Brazil. Wetlands Ecology and Management. 2003;11(4):265-272. doi: https:// doi.org/10.1023/A:1025015600125.

Glaser M, Diele K. Asymmetric outcomes: assessing central aspects of the biological, economic and ocial sustainability of mangrove crab fishery, Ucides cordatus (Ocypodidae), in North Brazil. Ecological Economics. 2004;49(3):361- 373.

Howard J, Hoyt S, Isensee K, Telszewski M, Pidgeon E (eds.). Coastal blue carbon: methods for assessing carbon stocks and emissions factors in mangroves, tidal salt marshes, and seagrasses. Arlington, Virginia, USA: Conservation International, Intergovernmental Oceanographic Commission of UNESCO, International Union for Conservation of Nature; 2014.

Hong LC, Hemati ZH, Zakaria RM. Carbon Stock Evaluation of Selected Mangrove Forests in Peninsular Malaysia and its Potential Market Value. Journal of Environmental Science and Management. 2017;20(2):77-87.

International Panel on Climate Change - IPCC. IPCC Special Report Emissions Scenarios: A Special Report of IPCC Working Group III. Cambridge, UK: Cambridge University Press; 2001. 27 p.

Kauffman JB, Donato DC. Protocols for the measurement, monitoring, and reporting of structure, biomass, and carbon stocks in mangrove forests. Bogor, Indonesia: Center for International Forestry Research (CIFOR); 2012. CIFOR Working Paper no. 86. 50p.

Kairo JG, Wanjiru C, Ochiewo J. Net Pay: economic analysis of a replanted mangrove plantation in Kenya. Journal of Sustainable Forestry. 2009;28(3-5):395-414. doi: https://doi. org/10.1080/10549810902791523.

Lo MW, Mojiol AR, Saleh E. Diversity of mangroves ecosystem in Semporna mangrove forest. Borneo Science. 2011;28:8-17.

Revista Árvore 2019;43(5):e430503 
McLeod E, Salm RV. Managing mangroves for resilience to climate change. Gland, Switzerland: World Conservation Union (IUCN); 2006. $n^{\circ} 2$

McLeod E, Chmura GL, Bouillon S, Salm R, Björk M, Duarte CM, et al. A blueprint for blue carbon: toward an improved understanding of the role of vegetated coastal habitats in sequestering $\mathrm{CO} 2$. Frontiers in Ecology and the Environment. 2011;9(10):552-560. doi: https://doi. org/10.1890/110004.

Mojiol AR, Guntabid J, Lintangah W, Ismenyah M, Julius K, Liew KC, et al. Contribution of mangrove forest and socio-economic development of local communities in Kudat district, Sabah Malaysia. International Journal of Agriculture, Forestry and Plantation. 2016;2:1-8.

Moraes BC, Costa JMN, Costa ACL, Costa MH. Variação espacial e temporal da precipitação no estado do Pará. Acta amazonica. 2005;35(2):207-214.

Murdiyarso D, Purbopuspito J, Kauffman JB, Warren MW, Sasmito SD, Donato DC, et al. The potential of Indonesian mangrove forests for global climate change mitigation. Nature Climate Change. 2015;5:1089-1092. doi: https://doi.org/10.1038/ NCLIMATE2734.

Pinheiro MAA, Fiscarelli AG, Hattori GY. Growth of the mangrove crab Ucides cordatus (Brachyura Ocypodidae). Journal of Crustacean Biology. 2005;25(2):293-301 doi: https://doi. org/10.1651/C-2438.

Rönnbäck P. The ecological basis for economic value of seafood production supported by mangrove ecosystems. Ecological Economics 1999;29(2):235-252.
Russell M, Greening H. Estimating Benefits in a Recovering Estuary: Tampa Bay, Florida. Estuaries and Coasts. 2015;38:9-18. doi: http://doi.org/10.1007/ s12237-015-9946-2.

Sathirathai S, Barbier EB. Valuing mangrove conservation in southern Thailand. Contemporary Economic Policy. 2001;19(2):109-122. doi: http://doi. org/10.1111/j.1465-7287.2001.tb00054.x.

Salem M, Mercer DE. The Economic Value of Mangroves: A Meta-Analysis. Sustainability. 2012;4(3):359-383. doi: https://doi.org/10.3390/ su4030359.

Singh S, Nag SK, Kundu SS, Maity SB. Relative intake, eating pattern, nutrient digestibility, nitrogen metabolism, fermentation pattern and growth performance of lambs fed organically and inorganically produced cowpea hay-barley grain diets. Trop. Grass. 2010;44(1):55-61.

Vo QT, Kuenzer C, Vo QM, Moder F, Oppelt N. Review of valuation methods for mangrove ecosystem services. Ecological Indicators. 2012;23:431-446. doi: http://doi.org/10.1016/j.ecolind.2012.04.022.

Warren-Rhodes K, Schwarz AM, Boyle LNG, Albert J, Agalo SS, Warren R, et al. Mangrove ecosystem services and the potential for carbon revenue programmes in Solomon Islands. Environmental Conservation. 2011;38(4)485-496. doi: http:// doi:10.1017/S0376892911000373.

World Bank Group. Carbon Pricing Watch. Publishing Physics Web. https://openknowledge. worldbank.org/handle/10986/26565, 2017. Accessed 02 de June 2018. 